\title{
Patent Holders for Government-Funded Research in Indonesia: What are the Consequences?
}

\author{
Budi Agus Riswandi ${ }^{*}$ \\ ${ }^{1}$ Faculty of Law, Universitas Islam Indonesia, Yogyakarta, Indonesia \\ *Corresponding author. Email: budiagusr@uii.ac.id
}

\begin{abstract}
The Indonesian government has issued a new research policy, in which government-funded research must be able to produce outcomes in the form of patents. From this new research policy, the government has released research funds to researchers of the state and private civil servants. From this policy, it has given birth to two kinds of legal relations, namely official and work relations. As a result, the results of government-funded research with this patent outcome have brought about the consequences of patent holders, rights and obligations of different patent holders. For the patent holder of the official relationship pattern, the government and inventor, while the patent holder of the employment relationship pattern, the government is the employer. In practice there has been a deviation of the consequences of patent holders, rights and obligations of patent holders on research results funded by the government both in official and employment relations. This can be seen from the name of the patent holder listed in the patent certificate. For official relations, the patent holder is only the government without an inventor, while for the employment relationship, the patent holder is private. This paper is presented to elaborate more deeply related to patent holders of government-funded research in Indonesia and its consequences. Normative juridical research methods with a statutory approach.
\end{abstract}

Keywords: patent holders, research, funded, government

\section{INTRODUCTION}

Since 2016, the Indonesian government has issued a new research policy in the form of output-based research. This output-based research focuses on research results that must be measurable, where research results can be in the form of publications and / or patents [1].

From this new research policy, the government has committed and realized a number of research budgets to encourage output-based research. With this step, researchers are expected to be able to produce quality and quality research and become research as a means of improving the national economy [2]. In line with the new research policy and the government's commitment to fund this research activity, many research activities have resulted in patented outcomes such as patents.

In the context of patent outcomes, it appears that this has created a problem relating to the status of the patent holder. This problem arises from the distribution of research funds from the government to two different researchers, namely researchers whose status is state and private civil apparatus. With the distribution of research funds from the government to different researchers, the legal relations created are different. For the relationship between the government and researchers with the status of private give birth to a working relationship, while the legal relationship between the government and researchers with the status as civil servants of the state give birth to official relations.

From these two legal relationships, the status of the patent holder is different for those who are engaged in an employment relationship, thus regulated in Article 12 (1) of
Law No. 13 of 2016 concerning Patents which states: The Patent Holder of the Invention produced by the Inventor in a work relationship is the party providing the work, unless otherwise agreed. Meanwhile, for those who have official relations, the patent holder is regulated in Article 13 paragraph (1) of Law No. 13 of 2016 which states: Patent Holders of Inventions produced by Inventors in official relations with government agencies are the said government agencies and Inventors, unless otherwise agreed.

From the existence of different legal provisions and legal relationships, it is interesting to write about patent holders for government-funded research. This attraction was also caused by the fact that in practice, the government and researchers further regulated ownership of patents through research agreements and patent applications. The further consequences of the different legal provisions and legal relations certainly have implications for the rights and obligations of the patent holder itself. Therefore, this paper also focuses on the issue of rights and obligations of patent holders whose research is funded by the government as a further consequence.

\section{RESEARCH METHOD}

The research method used is normative juridical with statutory approach. The normative juridical research method in this study sees the law as a rule by basing itself on the provisions of Law No. 13 of 2016, agreements and evidence of patent applications whose research is funded by the government. 


\section{RESULTS AND DISCUSSION}

\subsection{Patent Holder of the Results of Government-Funded Research in Indonesia}

Research is an academic activity which is expected to produce new knowledge and technology and be able to solve existing problems in society. To achieve these research objectives, the research must be able to produce solutions that are problem solving and create new technological products [3] that are competitive.

In line with this context, research is encouraged to produce patent outcomes. The choice of research output in the form of patents is given two reasons, namely; micro and macro reasons. In terms of micro reasons, the reasons are; (1). Research that produces patents in the past can focus more on solving problems; (2). Research that generates patents basically can be ascertained as novelty; and (3). Research that generates patents basically can produce innovations that must be applicable in the industry (industrial applicable). For macro reasons, namely; research that produces patents can support job creation [4] and improve social welfare [5]

By understanding the above reasons, there are many research schemes that are treated to produce patent outcomes by the government and the private sector. The German government, for example, since the early 1980s has been pushing research to produce new science and technology and is expected to create competitiveness [6]. In the Indonesian context, it seems that the Indonesian government has begun to push for research schemes funded by the government to be authenticated to produce patents. To support this, there are two things that have been done by the government, namely; (1). Prepare a series of research policies funded by the government to produce patents; and (2). Provide a research budget to support research schemes funded by the government to produce patents.

Specifically, in preparing a series of research policies funded by the government to produce patents, this is closely related to the pattern of distribution of research funds by the government to be given to two groups of researchers, namely; (1). Researchers with the status of Private; and (2). Researchers who have the status as State Civil Apparatus and. With the pattern of distribution of research funds by the government, it creates a different form of legal relationship. There are two legal relations that can be identified between the government and researchers, when the government funds research, namely; 1). legal relations in relation to the work context, which is known as work relations. For legal relations, this is conducted between the Government and the Private Sector; and 2). legal relations in the context of official services, known as official relationships. This legal relationship is conducted between the Government and the State Civil Apparatus.

For government-funded research in relation to official and employment relations, Law No. 13 of 2016 has set it clearly. One of the regulated matters is related to the patent holder. In Law No. 13 of 2016, there are two provisions governing it, namely; Provisions in Article 12 and Article 13 of Law No. 13 of 2016
According to the provisions of Article 12 (1) of Law No. 13 of 2016 states: Patent Holders of Inventions produced by Inventors in employment relationships are parties who provide jobs, unless otherwise agreed. Based on this provision, there are two things that can happen when the government funds research with researchers with the status of private, namely; First, if there is no agreement that deviates from the provisions of Article 12 (1) of Law No. 13 of 2016, the patent holder is the government; Second, if there is an agreement that deviates from the provisions of Article 12 (1) of Law no. 13 of 2016, the patent holder is jointly between the government and the inventor or the inventor himself.

After reviewing a research agreement between the government and the private sector, it can be found that the research agreement made with the agreement model does not deviate from the provisions of Article 12 (1) of Law No. 13 of 2016. This is stated in the research agreement carried out between the Government and Researchers from the private sector at Private Universities. In Article 7 (1) concerning intellectual property that reads intellectual property rights resulting from the conduct of research is regulated and managed in accordance with applicable laws and regulations. From this agreement clause, the patent holder is the government as the employer. In reality, when the patent application for research results is funded by the government, the patent holder is an inventor or a private university. This of course, has violated the provisions of Article 12 (1) of Law No. 13 of 2016 and the research agreement itself. Supposedly, if you want to deviate from the provisions of Article 12 (1) of Law no. 12 of 2016, the research agreement explicitly states that the patent holder is the inventor or private university. With a clause like this, the patent holder in this case the inventor or private university becomes legally valid.

Furthermore, the provisions of Article 13 (1) of Law No. 13 of 2016 states: Patent holders of inventions produced by inventors in official relations with government agencies are the said government agencies and inventors, unless otherwise agreed. After reviewing the research agreement between the government and researchers from the State Civil Apparatus at the State University it can be found that the research agreement in the case of the patent holder follows the provisions of Article 13 (1) of Law No. 13 of 2016. However, if you look at the patent application aas the results of research funded by the government, the patent holder is a State University in this case the government. With this fact, it has deviated from the provisions of Article 13 (1) of Law No. 13 of 2016 and the research agreement itself. Supposedly, if you want to deviate from the provisions of Article 13 (1) of Law No. 13 of 2016, the research agreement explicitly states that the patent holder is an inventor or a state university as a government, so that the legal status of the patent holder is legally valid. 
two types of patent holders, namely the government and inventors for official relationship patterns, while the government as employers for employment relations patterns. With these two types of patent holders, rights and obligations become different. However, the facts obtained by examining the patent application for research results funded by the government, it can be seen that the patent holder is a private non-government as an employer for employment patterns, while the patent holder resulting from research funded by the government, the patent holder is the government alone without including inventors for service relations. From this fact, the status of the patent holder has deviated from the provisions of Article 12 (1) and Article 13 (1) of Law No. 13 of 2016 and research agreement. As a result, the rights and obligations of both patent holders in both work relationships and service become null and void. employer.

From this situation the consequences of patent rights and obligations are different. For research funded by the government and carried out by the state civil apparatus, the rights of patent holders are (1). the government and inventors jointly hold exclusive and negative rights; (2). The government gives approval so that inventors can carry out their patents with third parties; (3). the government and inventors jointly have the right to transfer to other parties; and (4). the government and inventor together have a right to sue; For obligations, the patent holder is (1). the government and inventor must jointly pay an annual fee; and (2) the government grants the inventor's right to obtain a Patent Benefit which he produces from non-tax state revenue sources.

For research funded by the government and conducted by the private sector, the rights of patent holders are (1). the government as an employer holds exclusive and negative rights; (2) the government as the employer has the right to transfer to another party; (3). the government as an employer is entitled to get compensation; and (4). the government gives approval to give rewards to inventors; and (5). the government as an employer has suing rights. The obligations for patent holders are (1). the government as an employer is obliged to provide rewards to inventors by taking into account economic benefits; (2). The government as an employer must pay an annual fee.

In practice, the rights and obligations of patent holders from government-funded research through researchers in the state and private civil servants are actually very closely related to the status of patent holders from research results funded by the government. As stated above, that government-funded research conducted by researchers of both the state and private civil apparatuses, which later gave birth to patent holders, deviates from the provisions of Article 12 (1) and Article 13 (1) of Law No. 13 of 2016, the rights and obligations of patent holders are null and void. This implies the status of the patent holder is invalid and consequently does not give birth to rights and obligations as stipulated in Law No. 13 of 2016 and the research agreement itself.

\section{CONCLUSION}

When referring to Law No. 13 of 2016 and research agreements, the government-funded research has produced

\section{REFERENCES}

[1] Albert G.Z. Hu and I.P.L. Png, (2013), Patent Rights and Economic Growth: Evidence from CrossCountry Panels of Manufacturing Industries, Oxford Economic Papers, doi:10.1093/oep/gpt011.

[2] Dirk Czarnitzki and Andreas Fier, (2004), Publicly Funded R\&D Collaborations and Patent Outcome in Germany, Discussion Paper No. 03-24.

[3] Gregorio Giménez; (2017), The Impact of the Patent System on the Social Welfare: A Critical View, Intangible Capital - https://doi.org/10.3926/ic.789.

[4] Nicolas van Zeebroecko, Bruno van Pottelsberghe de la Potterie $\alpha$ and Dominique Guellec, (2008), Patents and Academic Research: A State of the Art, the Journal of Intellectual Capital, Volume 9, Issue 2, 2008.

[5] Raul Kartusa and Ants Kukrus, (2013), Innovation, Product Development and Patents at Universities, Estonian Journal of Engineering, 2013, 19, 1, doi: 10.3176/eng.2013.1.02.

[6] Rifat Atun, (2006), Innovation, Patents and Economic Growth, International Journal of Innovation Management.

https://www.researchgate.net/publication/23751118, date accessed 18 October 2019.

[7] Wenkai Tzeng, (2017), Poverty and Patents: Intellectual Property Policy and Economic Inequality, Indiana Journal of Law and Social Equality, Vol 5 Issue 2.

[8] Van Roy, Vincent and Vertesy, Daniel and Vivarelli, Marco, The Job-Creation Effect of Patents: Some Evidence from European Microdata (April 2016). Available at SSRN: https://ssrn.com/abstract=2770525 or http://dx.doi.org/10.2139/ssrn.2770525 